\title{
Determinants of Stock Returns on the Indonesian Stock Exchange
}

\author{
Aminullah Assagaf ${ }^{1}$, Meithiana Indrasari², Eddy Yunus ${ }^{3}$ \\ \{assagaf29@yahoo.com ${ }^{1}$ \} \\ ${ }^{1,2,3}$ Faculty of Economics and Business, Dr. Soetomo University, Surabaya, Indonesia
}

\begin{abstract}
This study aimed to analyze the factors that affect stock returns in the Indonesia Stock Exchange, by selecting a sample of 20 companies listed on the stock group LQ 45 with the observation in the last three years. Our research found that variable $\mathrm{X} 2$ liquidity or significant effect on stock return because this variable is considered very strategic in influencing smooth operations and financial performance. Other independent variables no significant effect on stock returns, mainly due to the decision of investors tend to be oriented on short-term margin trends. Changes to some of the key variables are not responded to by the investor, it is evident in the relatively small determinant coefficient,
\end{abstract}

Keywords: Financial management, portfolio management, risk management.

\section{Introduction}

This study aimed to analyze the phenomenon of uncertainty over the company's stock price in the Indonesia Stock Exchange or IHSG characterized by fluctuations in the stock price index or stock index over the period 2018-2019, for example IHSG early March $2018=6.606$; mid-November $2018=5.858$, down 11.3\%; and the beginning of March $2019=6.500$, up $11.0 \%$.

JCI reflecting the whole company listed on the Indonesia Stock Exchange shows that companies are individually experiencing varying patterns, but generally, follow the trend of the index. For investors in the Indonesia Stock Exchange, reflecting uncertainty is high, because the rate of return obtained from the difference between the stock prices at the level of time-varying risk levels are high.

At a high level of risk is the potential that can be exploited by investors on stock exchanges by making a purchase in the event of a downward trend and sell it when the price increases. Decisions and predictions are less accurate will affect investors' increased risk side. Conversely, with a precise estimate provides an opportunity for investor's decent returns. This phenomenon raises risk issues for investors in the stock exchange and is a research gap because it has not provided information that is able to answer these problems.

To eliminate the level of risk faced by investors in the Indonesia Stock Exchange, it is necessary to know the key factors that influence the rise and fall of stock prices in the Indonesia Stock Exchange. In addition, each of the explanatory variables needs to be measured significance level of influence on stock prices that reflect both the stock return.

The phenomenon was to motivate this research for identifying the various references and theories that can be used to explain the phenomenon. Research Arista (2012) uses several independent variables that affect stock returns, the return on assets (X1), debt to equity (X2), earnings per share (X3), and price to book value (X4). While research and Sriwidodo Kristiana [1] uses the independent variable that affects stock returns, the return on investment 
(ROI), return on equity (ROE), economic value added (EVA), and earnings per share (EPS). Based on reference and empirical conditions of the factors that affect the stock return, this study used an independent variable, namely profitability or X1, liquidity or X2,

From the aspect of reference theory, then the theory upon which this empirically is agency theory and signaling theory. It is associated with management actions to meet the interests of shareholders and present the information in the form of a signal to market participants that would affect stock prices and the impact on stock returns. In connection with the second theory, the study predicts that stock returns are influenced by the level of profitability, liquidity, and earnings management practices undertaken by the company.

Based on the description above, this research is important to provide a reference for investors on the Indonesian stock exchange and give input like company management in decision-making processes, especially associated with the key variables that affect the stock price of the company concerned.

\subsection{Main Problem}

Based on this phenomenon above, the following was stated the fundamental issues that will be examined in this study, namely: (a) whether the development of profitability significant effect on stock returns on the Indonesian stock exchange, (b) whether the level liquidity significant effect on stock returns on the Indonesian stock exchange, (c) whether the accrual-based earnings management have a significant effect on stock returns on the Indonesian stock exchange, (d) whether the real activities-based earnings management have a significant effect on stock returns on the Indonesian stock exchange, ( e) whether the debt to equity leverage profitability moderating influence on stock returns on the Indonesian stock exchange, and (f) whether the leverage of debt to equity moderating effect of liquidity on stock returns on the Indonesian stock exchange.

\section{Literature and Hypothesis}

The discussion in this study using a foundation of agency theory, signaling theory, and research previously associated with the variables used in this study.

\subsection{Agency Theory}

Theoretical basis used in this study is the agency theory developed by Jensen and Meckling as in Assagaf, et al. [2] arguing that this theory explains the two parties have different interests, namely the shareholders or principals who want to maximize dividend income or earnings per share, while managers of companies who want to maximize the receipt of compensation. Managers can manage the company to achieve the desired goals of shareholders and managers will be paid a decent amount of compensation to be motivated in carrying out its duties and responsibilities. The role of manager of the company is very important because it is closely related to variables that affect stock returns on the Indonesian stock exchange.

\subsection{Signalling Theory}

Melewar and Tucker (2005) as in Assagaf, et al. [2] suggests that the signaling theory shows that the company will give a signal through action and communication. The company adopts the signal in revealing the hidden attributes of stakeholders. The company strives to provide information through the financial report, gives a signal about the various factors that 
affect the company's financial condition, and communicate the strategy and policy measures to improve financial performance. This study uses signaling theory as the basis for the analysis of stock returns on the Indonesian stock exchange.

\subsection{Stock Returns}

Stock returns as a percentage of the results obtained from the difference between the current stock price periods with the share price the previous period, divided by the share price of the previous period. The variable stock return has been used in some previous studies as performed by Arista [3], Suharli [4], Kristiana and Sriwidodo [1].

Arista [3] found that the only variable debt to equity ratio and price to book value variables that significantly influence the stock return, while other variables had no significant effect. Suharli [4] found that stock returns are influenced by two variables, namely the debt to equity ratio and beta stocks. While research and Sriwidodo Kristiana [1] found that only the economic value added variables that significantly influence the stock return on the Indonesian stock exchange.

\subsection{Profitability}

Previous work by Carlo [5] found that the return on equity has a significant effect on stock returns. Similar to the reference, this research hypothesis H1 hypothesized as follows.

H1: Profitability positive and significant effect on stock returns on the Indonesian stock exchange.

\subsection{Liquidity}

Previous research conducted by Sutriani [6] found that liquidity significant effect on stock returns. Similar to the reference, this research proposes the following hypothesis H1.

H2: The level of liquidity and a significant positive effect on stock returns on the Indonesian stock exchange.

\subsection{Earnings Management}

Ambarwati [7] and Muid [8] to find that earnings management significantly the impact on stock returns. Similar to the reference to the study, this research put forward the hypothesis $\mathrm{H} 3$ and $\mathrm{H} 4$ below.

H3: Accrual-based earnings management and significant positive effect on stock returns on the Indonesian stock exchange.

H4: Real earnings management activities-based positive and significant effect on stock returns on the Indonesian stock exchange.

\subsection{Leverage}

Research Haryanto [9] to find that the variable leverage as a moderating variable that strengthens the relationship between the independent variable with stock returns. Similar to the reference to the study, this research put forward the hypothesis H5 and H6 below.

H5: Debt to equity leverage profitability moderating influence on stock returns on the Indonesian stock exchange.

H6: Debt to equity leverage to moderate the influence of liquidity on stock returns on the Indonesian stock exchange. 


\section{Operational Framework}

The operational framework of the study as figure 1 is intended to facilitate analysis of variables associated with stock returns. From these images show that the independent variable is used to answer the problem of this research, namely profitability growth or X1, liquidity or $\mathrm{X} 2$, or $\mathrm{X} 3$ accrual earnings management and real earnings management activities or X4.

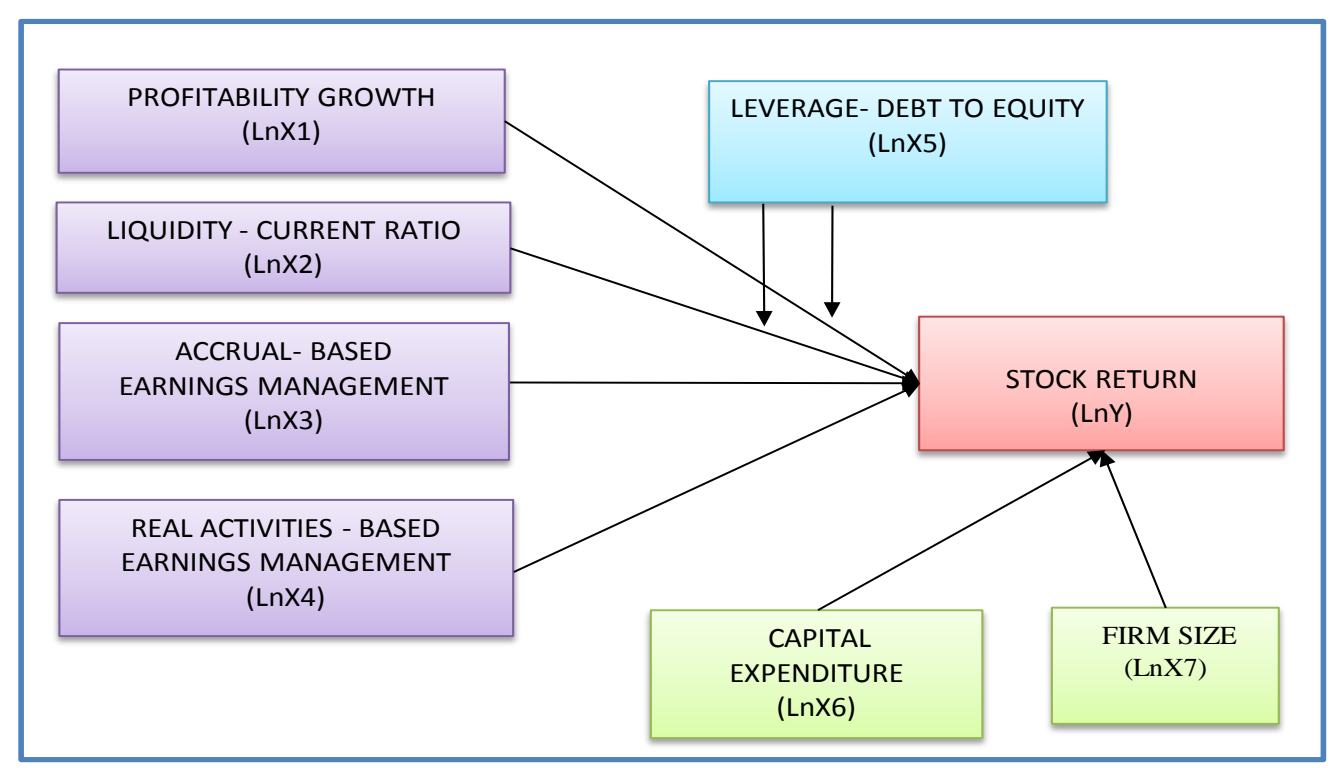

Fig. 1. The determinant of stock return

To show the results of a more comprehensive analysis as described in the operational framework, then this experiment using two control variables, namely capital expenditure or firm size or X6 and X7. Both variable control is intended to anticipate the impact if these variables are ignored.

This study also uses leverage as a moderating variable to analyze the role of these variables in strengthening or weaken the relationship between profitability with stock returns, and the relationship between liquidity with stock returns.

\section{Methodology}

\subsection{Population and sample}

To answer the problem and prove the hypothesis, this study presented using purposive sampling method, which determines the sample with the most active shares traded criteria and is considered to be considered representative of the population [10]. Selected companies is companies most actively traded shares on the Indonesian stock exchange during the last 3 years. For the determination of the sample, selected group of companies listed on the group LQ 45 , by selecting the 20 companies. So that observations in the study were 60 -year Company. 
4.2 Definitions and measurement variables

\subsubsection{Stock return $(Y)$}

Stock return is defined as the return generated from the difference between the stock prices of the current period $(\mathrm{t})$ with a stock price of the previous period $(\mathrm{t}-1)$. Stock returns are measured by using a formula as research Suharli [4] below.

$$
\mathrm{Y}=\frac{P(t)-P(t-1)}{P(t-1)}
$$

Where: $\mathrm{Y}=$ stock return, $\mathrm{P}(\mathrm{t})=$ stock price this year, $\mathrm{P}(\mathrm{t}-1)=$ share price the previous year.

\subsubsection{Profitability growth $(\mathrm{X} 1)$}

Growth in profitability is defined as the percentage change between the return on equity (ROE) of the current period ( $\mathrm{t}$ ) with a return on equity (ROE) of the previous period ( $\mathrm{t}-1)$. Growth in profitability is measured by using a formula as research Carlo [5] below.

$$
\mathrm{X} 1=\frac{R O E(t)-R O E(t-1)}{R O E(t-1)}
$$

\subsubsection{Liquidity (X2)}

The company's liquidity is the company's ability to pay short-term debt maturities. Liquidity is measured by using a formula as research Lestari, et al. [11] below.

$$
\mathrm{X} 2=\frac{\text { Current asset }}{\text { Current liabilities }}
$$

\subsubsection{Accruals-based earnings management (X3)}

Accruals basis earnings management is committed to the management practices affect the company's financial statements using accruals transaction. Variable earnings management is measured by using a formula measuring the total accruals as Habib (2004), Baharuddin and Setyanugraha (2008) in Assagaf, et al. [2] the following,

$\mathrm{X} 3=\mathrm{ACEM}=(\triangle \mathrm{CA}-\Delta \mathrm{Cash})-(\Delta \mathrm{CL}-\Delta \mathrm{STD})-$ Depreciation

Where: $\mathrm{X} 3$ or ACEM is total accruals; $\triangle \mathrm{CA}$ is a change in current assets; $\triangle \mathrm{CL}$ is a change in current liabilities; $\triangle \mathrm{Cash}$ is the change in cash and cash equivalents. $\triangle \mathrm{STD}$ is debt that is included in current liabilities.

\subsubsection{Real earnings management activities (X4)}

Earnings management activities are the real basis of management practices that do to influence the company's financial statements by using transactions related to the increase in credit sales with discounts excessive increase in an average cost of production for pressing and pressing the discretionary expenditures that are not directly related to revenues or profits. Measurement activities of real variables used in this study are outlined in Roychowdhury (2006) in Assagaf, et al. [2] below.

Equation (1): Cash flow operation (CFO),

$\mathrm{CFO}_{\mathrm{t}} / \mathrm{A}_{\mathrm{t}-1}=\alpha_{0}+\alpha_{1}\left(1 / \mathrm{A}_{\mathrm{t}-1}\right)+\beta_{1}\left(\mathrm{~S}_{\mathrm{t}} / \mathrm{A}_{\mathrm{t}-1}\right)+\beta_{2}\left(\Delta \mathrm{S}_{\mathrm{t}} / \mathrm{A}_{\mathrm{t}-1}\right)+\mathrm{e}_{\mathrm{t}}$

Equation (2): Cost of goods sold (COGS),

$\operatorname{COGS}_{t} / \mathrm{A}_{\mathrm{t}-1}=\alpha_{0}+\alpha_{1}\left(1 / \mathrm{A}_{\mathrm{t}-1}\right)+\beta\left(\mathrm{S}_{\mathrm{t}} / \mathrm{A}_{\mathrm{t}-1}\right)+\mathrm{e}_{\mathrm{t}}$ 
Equation (3): Change in inventory ( $\triangle \mathrm{INV})$,

$\Delta \mathrm{INV}_{\mathrm{t}} / \mathrm{A}_{\mathrm{t}-1}=\alpha_{0}+\alpha_{1}\left(1 / \mathrm{A}_{\mathrm{t}-1}\right)+\beta_{1}\left(\Delta \mathrm{S}_{\mathrm{t}} / \mathrm{A}_{\mathrm{t}-1}\right)+\beta_{2}\left(\Delta \mathrm{S}_{\mathrm{t}-1} / \mathrm{A}_{\mathrm{t}-1}\right)+\mathrm{e}_{\mathrm{t}}$

Equation (4): Production (PROD),

$\operatorname{PROD}_{\mathrm{t}} / \mathrm{A}_{\mathrm{t}-1}=\alpha_{0}+\alpha_{1}\left(1 / \mathrm{A}_{\mathrm{t}-1}\right)+\beta_{1}\left(\mathrm{~S}_{\mathrm{t}} / \mathrm{A}_{\mathrm{t}-1}\right)+\beta_{2}\left(\Delta \mathrm{S}_{\mathrm{t}} / \mathrm{A}_{\mathrm{t}-1}\right)+\mathrm{B}_{3}\left(\Delta \mathrm{S}_{\mathrm{t}-1} / \mathrm{A}_{\mathrm{t}-1}\right)+\mathrm{e}_{\mathrm{t}}$

Equation (5): Discretionary expense (DISEXP),

$\operatorname{DEXP}_{\mathrm{t}} / \mathrm{A}_{\mathrm{t}-1}=\alpha_{0}+\alpha_{1}\left(1 / \mathrm{A}_{\mathrm{t}-1}\right)+\beta\left(\mathrm{S}_{\mathrm{t}-1} / \mathrm{A}_{\mathrm{t}-1}\right)+\mathrm{e}_{\mathrm{t}}$

This variable measurement procedure begins by using equation (1) to equation (5), and then calculated the residual or abnormal from the fifth equation, namely:

$\mathrm{X} 4=\mathrm{AREALt}=\mathrm{ACFO}+\mathrm{ACOGSt}+\mathrm{A} \Delta \mathrm{INVt}+\mathrm{APRODt}+\mathrm{ADEXPt}$

Where: AREA $=\mathrm{X} 4$ or abnormal or residuals of the estate activities; $\mathrm{ACFO}=$ abnormal or residual operating cash flow; ACOGS = abnormal or residual cost of goods sold; $\mathrm{A} \triangle \mathrm{INV}=$ Abnormal or residual changes in inventory value; APROD $=$ abnormal or residual costs of production; $\mathrm{ADEXP}=$ abnormal or residual discretionary expense; At $=$ total assets, end of year $t$; St: sales period $t$.

\subsubsection{Leverage (X5)}

Leverage indicates the level of the use of debt to meet the funding needs of operation and investment programs of that company. Variable leverage measured by using a formula as research Haryanto [9] below.

$$
\mathrm{X} 5=\frac{\text { Total debt }}{\text { total aset }}
$$

\subsubsection{Capital expenditure (X6)}

Capital expenditure is to show the amount of investment made by the company in a given period. Measurements using a formula variable capital expenditure as research Rakhimsyah [12] below.

$$
\mathrm{X} 6=\frac{\text { Fixed assets }(t)-\text { Fixed assets }(t-1)}{\text { Fixed assets }(t-1)}
$$

\subsubsection{Firm size (X7)}

Firm size shows the value of assets used by the company as recorded in the financial statements a certain period. Measurements using a formula variable firm size as research Sudarsono et al. [13] below.

$$
\mathrm{X} 7=\log (\text { total assets) }
$$

\subsection{Model Analysis}

The model analysis used to test the hypothesis of this study is nonlinear models, arguing that the nonlinear analysis model has the ability to explain the phenomenon that is better (adjusted R2 $=0.162$ ) than the linear model (adjusted R2 $=0.102$ ). Nonlinear equation model used is based $\mathrm{Ln}$ as noted below.

$$
\begin{aligned}
& \mathrm{LNY}=\beta 0+\beta 1 \operatorname{LnX} 1+\beta 2 \operatorname{LnX} 2+\beta 3 \operatorname{LnX} 3+\beta 4 \operatorname{LnX} 4+\beta 5 \operatorname{LnX} 5+\beta 6 \operatorname{LnX} 6+ \\
& \beta 7 \operatorname{LnX} 7+\beta 8 \operatorname{LnX} 1 \mathrm{X} 5+\beta 9 \operatorname{LnX} 2 \mathrm{X} 5+\mathrm{e}
\end{aligned}
$$

Where: $\mathrm{LNY}=$ stock return, $\mathrm{LnX} 1=$ profitability growth, $\mathrm{LnX} 2=$ liquidity, $\mathrm{LnX} 3=$ accruals-based earnings management, $\mathrm{LnX} 4=$ estate activities earnings management, $\mathrm{LnX} 5=$ leverage of debt to equity, $\operatorname{LnX6}=$ capital expenditure, $\operatorname{LnX7}=$ firm size, $\operatorname{LnX1X5}=$ 
interaction $\mathrm{X} 1$ and $\mathrm{X} 5$, and $\mathrm{LnX} 2 \mathrm{X} 5=$ interaction $\mathrm{X} 2$ and $\mathrm{X} 5, \beta 0=$ constant, $\beta 1 \ldots . . \beta 9=$ coefficient, $\mathrm{e}=$ error 


\section{Result and Discussion}

\subsection{Descriptive Statistics}

Descriptive statistics as table 1 below, is to show the structure of each variable used in this study. Stock returns as dependent variable $\mathrm{Y}$ with the average value of -3.289 spread between the minimum value of -6.601 to -0.928 maximum, and the magnitude of the deviation value or a standard deviation of 1,144 .

The data structure independent variable, respectively, namely: (a) Profitably, or X1 is structured with the average value of -1.505 spread between the minimum value of -5.044 up to a maximum of 40 , and the amount of deviation, or standard deviation value of 1.164 ; (b) the liquidity or X2, structured with an average value of 724 spread between the minimum value of -798 up to a maximum of 1.944 , and the amount of deviation, or standard deviation value 681 ; (c) accrual base of earnings management or X3, structured with the average value of 1,019 spread between the minimum value of -2.011 up to a maximum of 4.220 , and the amount of deviation, or standard deviation value 1.034; and (d) real activities base earning management or X4, structured with the average value of -2.459 spread between the minimum value up to a maximum of $-322-6.370$,

Table 1. Descriptive Statistics

\begin{tabular}{lrrrrr}
\hline & $\mathrm{N}$ & Minimum & Maximum & \multicolumn{1}{c}{ Mean } & Std. Deviation \\
\hline LnY & 60 & $(6.601)$ & $(928)$ & $(3.289)$ & 1.144 \\
LnX1 & 60 & $(5.044)$ & 40 & $(1.505)$ & 1.164 \\
LnX2 & 60 & $(798)$ & 1.944 & 724 & 681 \\
LnX3 & 60 & $(2.011)$ & 4.220 & 1.019 & 1.034 \\
LnX4 & 60 & $(6.370)$ & $(322)$ & $(2.459)$ & 1.277 \\
LnX5 & 60 & $(1.873)$ & 2.825 & $(53)$ & 1.023 \\
LnX6 & 60 & $(6.822)$ & 917 & $(2.188)$ & 1.167 \\
LnX7 & 60 & 1.880 & 2.431 & 2.301 & 86 \\
LnX1X5 & 60 & $(5.218)$ & 2.251 & $(1.558)$ & 1.647 \\
LnX2X5 & 60 & $(1.358)$ & 4.254 & 740 & 1.197 \\
Valid N (listwise) & 60 & & & & \\
\hline
\end{tabular}

Where: $\mathrm{LNY}=$ stock return, $\mathrm{LnX} 1=$ profitability growth, $\mathrm{LnX} 2=$ liquidity, $\mathrm{LnX} 3=$ accruals-based earnings management, LnX4 = estate activities earnings management, LnX5 = leverage of debt to equity, LnX6 = capital expenditure, $\operatorname{LnX7}=$ firm size, LnX1X5 = interaction X1 and X5, and LnX2X5 = interaction X2 and X5.

Moderating variable data and variable control is structured as follows: (a) moderating variable leverage or X5, structured with the average value of -53 spread between the minimum value of -1.837 up to a maximum of 2.825 , and the amount of deviation, or standard deviation value of 1.023; (b) the control variable capital expenditure or X6, structured with the average value of -2.188 spread between the minimum value -6.822 up to a maximum of 917 , and the amount of deviation, or standard deviation value of 1.167; (c) the variable firm size or X7, structured with the average value of 2.301 spread between a minimum of 1.880 to a maximum value of 2.431, and the amount of deviation, or standard deviation value 86 . 


\subsection{Correlations}

Correlation analysis as table 2 below, which shows a linear relationship between each variable used in this study. The relationship between stock return variables with independent variables showed that the only variable affecting liquidity exhibited significantly on stock returns, while the other independent variables were not a significant influence on stock returns.

Table 2. Correlations

\begin{tabular}{lrrrrrrrrrr}
\hline & Y & \multicolumn{1}{c}{ X1 } & X2 & X3 & X4 & X5 & X6 & X7 & X1X5 & X2X5 \\
\hline LnY & 1 & & & & & & & & & \\
LnX1 & 0,215 & 1 & & & & & & & & \\
LnX2 & $.366^{* *}$ & 0,0767 & 1 & & & & & & & \\
LnX3 & 0,187 & 0,025 & 0,212 & 1 & & & & & & \\
LnX4 & $-0,195$ & $-0,126$ & $-.468^{* *}$ & $-0,208$ & 1 & & & & & \\
LnX5 & $-0,149$ & 0,131 & $-.261^{*}$ & $-0,071$ & $-0,002$ & 1 & & & & \\
LnX6 & 0,027 & 0,017 & $-.297^{*}$ & $-0,039$ & 0,098 & 0,172 & 1 & & & \\
LnX7 & $-0,241$ & $-0,178$ & $-0,032$ & $-0,029$ & 0,134 & $-0,074$ & $.276^{*}$ & 1 & & \\
LnX1X5 & 0,059 & $.788^{* *}$ & $-0,108$ & $-0,026$ & $-0,091$ & $.714^{* *}$ & 0,119 & $-0,172$ & 1 & \\
LnX2X5 & 0,017 & $-.254^{*}$ & $.312^{*}$ & $-0,232$ & 0,086 & $-0,153$ & $-0,227$ & 0,114 & $-.275^{*}$ & 1 \\
\hline
\end{tabular}

*. Correlation is significant at the 0.05 level (2-tailed).

${ }^{*}$. Correlation is significant at the 0.01 level (2-tailed).

The relationship between the independent variable with other independent variables occurs a significant correlation between variables liquidity or X2 with real activities-based earnings management or X4. The significance of the relationship between variables X2 and $\mathrm{X} 4$ have to be tested using linear models. The test results show that a linear relationship X2 tolerance value of 0.594 and $1.682 \mathrm{VIF}$, while the $\mathrm{X} 4$ variable tolerance value of 0.922 and $1.085 \mathrm{VIF}$, so that otherwise does not happen at 0.01 or $1 \%$ level. Classic assumption test only applies to linear regression models, nonlinear regression model whereas this study is not required test that assumption.

\subsection{Hypothesis Testing}

The simulation results with SPSS 25 as Table 3 shows that only hypothesis $\mathrm{H} 2$ or variable X2 which proved a positive and significant effect on stock returns. While the other variables do not support the hypothesis. Variable control is not put forward as a hypothesis, but a significant effect on stock returns, is capital expenditure or X6 significant positive effect on the level of $7.8 \%$, and firm size or X7 significant negative effect on the level of $3.4 \%$.

\subsection{Coefficient Regression}

The result of the calculation as table 3 shows the number of variables has a significant effect and the other is not significant or do not support the hypothesis. Independent variable $\mathrm{X} 2$ liquidity or positive effect 0.608 and significant at the $3 \%$ level, which means that each increase of one unit X2, will increase by 0.608 units of stock returns. The relationship that shows the influence of each of these variables on stock returns regression equation expressed as follows. 


$$
\begin{aligned}
\mathrm{LNY}= & 5543.6+0.157 \operatorname{LnX} 1+0.608 \operatorname{LnX} 2+0.125 \operatorname{LnX} 3++0.026 \operatorname{LnX} 4- \\
& 0.139 \operatorname{LnX} 5+0.235 \operatorname{LnX} 6-3.746 \operatorname{LnX} 7-354.3 \operatorname{LnX} 1 X 5+0.035 \operatorname{LnX} 2 X 5
\end{aligned}
$$

Control variables have a significant effect on stock returns, namely: capital expenditure or X6 has positive impact 0.235 which means that each increase of one unit of capital expenditure, will increase stock returns for 0.235 . While firm size or X7 has a negative effect -3.764 which means that each increase of one unit firm size will cause a decrease in stock returns amounted to 3,764 units.

Table 3. Coefficients

\begin{tabular}{lcrc}
\hline \multicolumn{1}{c}{ Variables } & Predict. & Coefficient & Significant \\
\hline (Constant) & & 5543,651 & 0,177 \\
LnX1 & + & 0,157 & 0,218 \\
LnX2 & + & 0,608 & $0,030 * *$ \\
LnX3 & + & 0,125 & 0,386 \\
LnX4 & + & 0,026 & 0,840 \\
LnX5 & + & $-0,139$ & 0,334 \\
LnX6 & + & 0,235 & $0,078 *$ \\
LnX7 & + & $-3,746$ & $0,034 * *$ \\
LnX1X5 & + & -354.319 & 0,369 \\
LnX2X5 & + & 0,035 & 0,805 \\
\hline Adjusted R ${ }^{2}$ & 0,162 & & \\
F-Statistics & 2,421 & & \\
Sig. & 0.000 & & \\
Obs & 60 & & \\
\hline
\end{tabular}

Where: $\mathrm{LNY}=$ stock return, $\mathrm{LnX} 1$ = profitability growth, $\mathrm{LnX} 2=$ liquidity, $\mathrm{LnX} 3=$ accruals-based earnings management, LnX4 = estate activities earnings management, LnX5 = leverage of debt to equity, LnX6 = capital expenditure, $\operatorname{LnX7}=$ firm size, $\operatorname{LnX} 1 \mathrm{X} 5=$ interaction X1 and X5, and LnX2X5 = interaction X2 and X5.

\subsection{Classic assumption test}

Classical assumptions when using linear regression models through normality test, autocorrelation test and test heteroskedasticity. While the nonlinear regression model as used in this study does not require the classical assumption test.

Selection of linear regression models or non-linear is dependent on the distribution of research data, which can be tested through a scatter plot and determinant coefficient test. The result may indicate selection tepa models Tantara linear or nonlinear models. To ensure the accuracy of our model, then tested the determinant coefficient, and the results show that the nonlinear regression model is more appropriate than the linear model. This means also that the study was not necessary to test a classic assumption.

\subsection{Determinant coefficient (adjusted $\mathbf{R}^{2}$ )}

Determinant coefficient calculation results (adjusted $\mathrm{R}^{2}$ ) indicates the value of 0.162 which means that the study was able to explain the phenomenon of $16.2 \%$. This indicates that the dependent variable changes in stock returns that are caused by changes in the independent 
variable, can be explained in the range of $16.2 \%$, and the remaining $83.8 \%$ is explained by other variables outside of this study. 


\subsection{Statistic-F}

Significant test the effect of independent variables on stock returns simultaneously shows that the value of the F-statistics $=2.421$ or 0.000 , which means that a significant independent variable significant effect on stock returns.

\subsection{Statistics-t}

After the simulant test statistic $\mathrm{F}$ test, then tested each independent variable partial influence on stock returns. Table 3 shows that the variables that significantly influence the stock return, namely: (a) the independent variable X2 significance level of liquidity or 0.030 , or 3\%, (b) variable control of capital expenditure or X6 is a significant level of 0.078 or $7.8 \%$, and (c) control variables firm size or X7 significant level of 0.034 or $3.4 \%$. While other variables, namely $\mathrm{X} 1, \mathrm{X} 3, \mathrm{X} 4$ and $\mathrm{X} 5$ not significant effect on the dependent variable stock returns on the Indonesian stock exchange.

\subsection{Discussion}

Based on Table 3 shows the regression coefficients, t-test statistics, test statistics-F, and the coefficient determinant or adjusted $\mathrm{R}^{2}$, explained that the independent variables that have a significant effect only variable liquidity or X2, while the other independent variables had no significant effect. This is mainly due to the liquidity role for the smooth operation of the company and supports the acquisition of a decent level of profitability. Increasing the value of the variable X2 will provide an attraction for investors to choose the company's shares in their investment decisions.

Other independent variables such as $\mathrm{X} 1, \mathrm{X} 3$, and $\mathrm{X} 4$ no significant effect on stock returns, mainly because investors tend to do transaction-oriented short-term margins. Decision investors simply follow the trend of demand and supply on the Stock Exchange, and only pay attention to the key variables that are considered strategic in determining the smooth operation of the company, such as liquidity or X2 described above.

A significance level of influence of the independent variable X2 and the decision of investors who tend to do short-term speculation, as evidenced in 0.162 determinant coefficient levels are relatively small. This means also that the investor's decision is influenced by many factors other than the key factors used in this study. Investors simply tend to pay attention to short-term fluctuations of the stock price, so that the frequency of extremely smooth transaction for investors buying or selling in a relatively short period of time, such as weekly or monthly.

Variable control capital expenditure or X6 and X7 firm size or significant effect on stock returns, which means that the two variables have been functioning well as a control variable. When not used as a control variable, then this variable could potentially lead to bias or influence the outcome of this study.

While variable leverage or X5 is not a significant effect on stock returns, and function as a moderating variable indicates that this variable does not moderate the effect of variable profitability and liquidity on stock returns.

\section{Conclusion}

Based on the results of the analysis of the above, it can be concluded, namely: (a) the independent variable X2 liquidity or significant effect on stock returns, mainly because of this variable response by investors as a variable that affects the smooth operation and performance 
of the company. (b) Other independent variables such as X1, X3, and X4 no significant effect on stock returns mainly because investors tend to speculate on short-term margin trends, and only pay attention to the strategic key variables such as X2 mentioned above. (c) This study describes the phenomenon only approximately $16.2 \%$ as a coefficient determinant or adjusted $\mathrm{R}^{2}=0.162$, and the remaining $83.8 \%$ is explained by other variables outside variables of this study.

\section{References}

[1] V. A. Kristiana and U. Sriwidodo, “Analisis Faktor-Faktor Yang Mempengaruhi Return Saham Investor Pada Perusahaan Manufaktur di Bursa Efek Indonesia," $J$. Ekon. dan Kewirausahaan, 2012.

[2] A. Assagaf, E. Murwaningsari, J. Gunawan, and S. Mayangsari, "Estimates Model of Factors Affecting Financial Distress: Evidence from Indonesian State-owned Enterprises," Asian J. Econ. Bus. Account., pp. 1-19, 2019.

[3] D. Arista and A. Astohar, "Analisis Faktor-Faktor Yang Mempengaruhi Return Saham," J. Ilmu Manaj. dan Akunt. Terap., vol. 3, no. 1, 2012.

[4] M. Suharli, "Studi empiris terhadap dua faktor yang mempengaruhi return saham pada industri food \& beverages di bursa efek jakarta," J. Akunt. Keuang., 2004.

[5] M. A. Carlo, "Pengaruh Return On Equity, Dividend Payout Ratio, dan Price to Earning Ratio pada Return Saham," E-jurnal Akunt. Univ. Udayana, 2014.

[6] A. Sutriani, "PENGARUH PROFITABILITAS, LEVERAGE, DAN LIKUIDITAS TERHADAP RETURN SAHAM DENGAN NILAI TUKAR SEBAGAI VARIABEL MODERASI PADA SAHAM LQ-45," J. Bus. Bank., 2014.

[7] S. D. A. Ambarwati, "Pengujian Week-Four, Monday, Friday dan Earnings Management Effect Terhadap Return Saham," J. Keuang. dan Perbank., vol. 13, no. 1, pp. 1-14, 2009.

[8] D. Muid, "Pengaruh Manajemen Laba terhadap Kinerja Operasi, Return Saham pada Perusahaan Publik di Bursa Efek Jakarta (BEJ)," J. Din. Ekon. Bisnis, vol. 4, no. 2, 2007.

[9] C. M. HARYANTO, "PENGARUH RELEVANSI LABA AKUNTANSI TERHADAP RETURN SAHAM DENGAN RISIKO PERUSAHAAN DAN LEVERAGE SEBAGAI VARIABE PEMODERASI PADA PERUSAHAAN MANUFAKTUR DI BEI," J. Ilm. Mhs. Akunt., 2012.

[10] M. Indrasari, I. N. Hapsari, and S. Sukesi, "Customer loyalty: effects of sales information system, marcomm, and brand ambassadors," J. Stud. Komun., vol. 3, no. 2, pp. 182-198, 2019.

[11] K. Lestari, R. Andini, and A. Oemar, "Analisis Likuiditas, Leverage, Profitabilitas, Aktivitas, Ukuran Perusahaan dan Penilaian Pasar Terhadap Return Saham (Pada Perusahaan Real Estate dan Property di BEI) Periode Tahun 2009-2014," J. Account., vol. 2, no. 2, 2016.

[12] L. Amnah Rakhimsyah and B. Gunawan, "PENGARUH KEPUTUSAN INVESTASI, KEPUTUSAN PENDANAAN, KEBIJAKAN DIVIDEN DAN TINGKAT SUKU BUNGA TERHADAP NILAI PERUSAHAAN," 2011.

[13] B. S. Bambang Sudarsono, "FAKTOR-FAKTOR YANG MEMPENGARUHI RETURN SAHAM PADA PERUSAHAAN PROPERTY DAN REAL ESTATE YANG TERDAFTAR PADA BURSA EFEK INDONESIA TAHUN 2009 S/D 2014," Bisnis dan Ekon., 2016. 